\title{
USING SOCIAL MEDIA FOR CUSTOMER KNOWLEDGE MANAGEMENT IN DEVELOPING ECONOMIES: A SYSTEMATIC REVIEW
}

\author{
Martinson Ofori, Dakota State University, martinson.ofori@trojans.dsu.edu \\ Omar El-Gayar, Dakota State University, omar.el-gayar@dsu.edu
}

\begin{abstract}
Knowledge Management (KM) research has theorized that KM activities lead to better firm performance. The current view that there is more external knowledge than exists within organizations has resulted in a preference for customercentric approaches over traditional KM activities. Recent advances in technology has resulted in social media use as an avenue for knowledge creation from the social interaction between brands and their customers. Most research however explore social media's impact on organizational knowledge in developed economies with little attention to developing economies where KM could be conceptualized differently. In this research, we analyze the extent to which social media can support customer knowledge management (CKM) in developing economies. Using a systematic literature review, the current study captures literature containing keywords on social media and CKM published in relevant databases between January 2010 and December 2019. Finding from this study demonstrated that the strategies employed in developing economies largely depend on the type of social media and strategies can be made more effective through channel, engagement, and business intelligence management. It was also discovered that knowledge creation was the most important KM process for ensuring success while the systems that support this were a combination of Marketing, Sales, Customer Service, and Technology.
\end{abstract}

Keywords: customer knowledge management, social media, developing country, low-income economy

\section{INTRODUCTION}

The traditional factors of production - land, labor, capital - are no longer considered primary but have become secondary to the only meaningful resource of today: knowledge (Drucker, 1992). Rowley (2002) asserts that a part of this resource that remains an important asset to businesses is customer knowledge (CK). Customer knowledge management requires leveraging three types of knowledge: from, about, and for potential customers, customer segments and individual customers (Desouza \& Awazu, 2005; Rowley, 2002). Organizations that possess this kind of knowledge may achieve competitive advantage (García-Murillo \& Annabi, 2002; Khodakarami \& Chan, 2014; Winer, 2001).

Competitive advantage is realized by including customer views into the decision-making process which in turn reduces, as much as possible, uncertainty from business processes (Applegate et al., 2009). The world wide web, and in extension the Internet and social media, has created an avenue for businesses to manage this interaction with customers (Winer, 2001). Social media, especially, has become an integral part of a firm's strategy for knowledge creation as it allows seamless social interaction between brands and their customers. In fact, business decision makers and their consultants often seek ways in which social media platforms - Twitter, Facebook, YouTube, etc. - can be used profitably (Kaplan \& Haenlein, 2010).

The problem is that even with the myriad of options available, customers can have a difficult time communicating their needs and demands. Businesses are required to employ the most effective tools to ensure communication with customers remain optimum (Tseng \& Wu, 2014). Dous et al. (2005) posits that successful implementation of CKM in practice involves four elements: strategy, processes, systems, and change management. Accordingly, this research investigates how literature has applied the first three elements to CKM using social media. The study leverages extant literature on the topic of CKM and social media from the perspective of developing economies with the aim of exploring how CKM could be conceptualized differently in a low-income economic country. Specifically, the present study systematically reviews and synthesizes the CKM-related studies in developing economies with the focus on social media by posing the following research questions:

RQ1. What are the strategies used for CKM in developing countries?

RQ2. Which CKM processes are most prevalent in studies for ensuring and promoting customer success? 
RQ3. How are systems implemented to support social media for customer relationship management in developing countries?

The rest of this study is organized as follows: the ensuing section describes the background and theoretical framework for synthesizing literature in this review. This is followed by the research methodology and findings. Further, we present an in in-depth discussion of the findings with respect to the proposed research questions and conclude with implications for research and practice.

\section{BACKGROUND AND THEORETICAL FRAMEWORK}

\section{Customer knowledge management (CKM)}

Customer knowledge is viewed as a major resource for organizations as it is often sufficient for managing and supporting research and development of new products (Gibbert et al., 2002). Constant interaction with customers allows the organization to analyze and understand the customers' knowledge of the firm itself, and its products, services, suppliers, and markets. This knowledge is essential for making continuous improvements to the firms business model and services, and for new product development (García-Murillo \& Annabi, 2002). Other types of customer knowledge that can be beneficial to a firm includes their knowledge of the firm's competitors and market trends which can be used as a feedback mechanism to deliver systematic improvements and innovation to products. Three customer knowledge types are discussed in the literature:

The first type of knowledge is the one for customers. Customer education is an essential part of CKM. By supplying customers with information on products, services, suppliers, distribution channels, prices, and even major developments within the firm, customers are afforded the requisite help for making the best purchasing decisions. Customer's perception of service quality is often affected by this type of knowledge (Desouza \& Awazu, 2005). As such, it is vital to not only communicate product information, but also financial information, and even service and supply disruptions.

Second, knowledge from customers is gathered based on customer behavior such as buying patterns. This leads to a deeper understanding of their motivations which can, in turn, be leveraged to improve customer service. In recent times, social media has provided an additional dimension to this type of knowledge collection as it permits segmentation through sales prospect profiling (Vijay \& Srivastava, 2019). For example, Facebook can be leveraged for information on customer's age group and interests, Amazon for product choices, and LinkedIn for information on customer's professional interests. This allows firms to tailor marketing campaigns towards certain individuals and in some situations create different product lines for different segments.

Last, knowledge about customers requires conscious management of customers' knowledge which, in turn, allows firms to meet their customers' ever-changing needs through a continuous communication loop (Davenport et al., 2001). This is because CKM is a continuous cycle of acquiring and processing valuable customer information through various channels and sharing this processed information - customer knowledge - within the business. CKM creates strategic processes that change a firm's customer from a passive recipient of information to a partner whose adequate knowledge can be used to profit the business (Plessis \& Boon, 2004).

\section{Theoretical Framework}

As shown in Figure 1, this systematic review discusses extant literature on the background of the types of CKM and elements of CKM implementation introduced by Dous et al. (2005). These elements, as mentioned in the earlier were introduced by the authors to alleviate the gap between the benefits in theory and successful practice. We discuss each of the types of knowledge mentioned above (from, to, and about customers) along the lines of the four elements:

- Strategy: It perceives CK as a valuable source of product innovation and process improvement.

- Processes: Are used to align knowledge management activities seamlessly with CRM processes.

- Systems: Create an integrated knowledge repository across organizational boundaries.

- Change management: to encourage relationship managers to capture and disseminate customer knowledge 
However, for the purposes of this research, change management is not discussed as research into it has been lacking in the literature. Figure 1 presents a conceptual view of how the literature has been organized in this study.

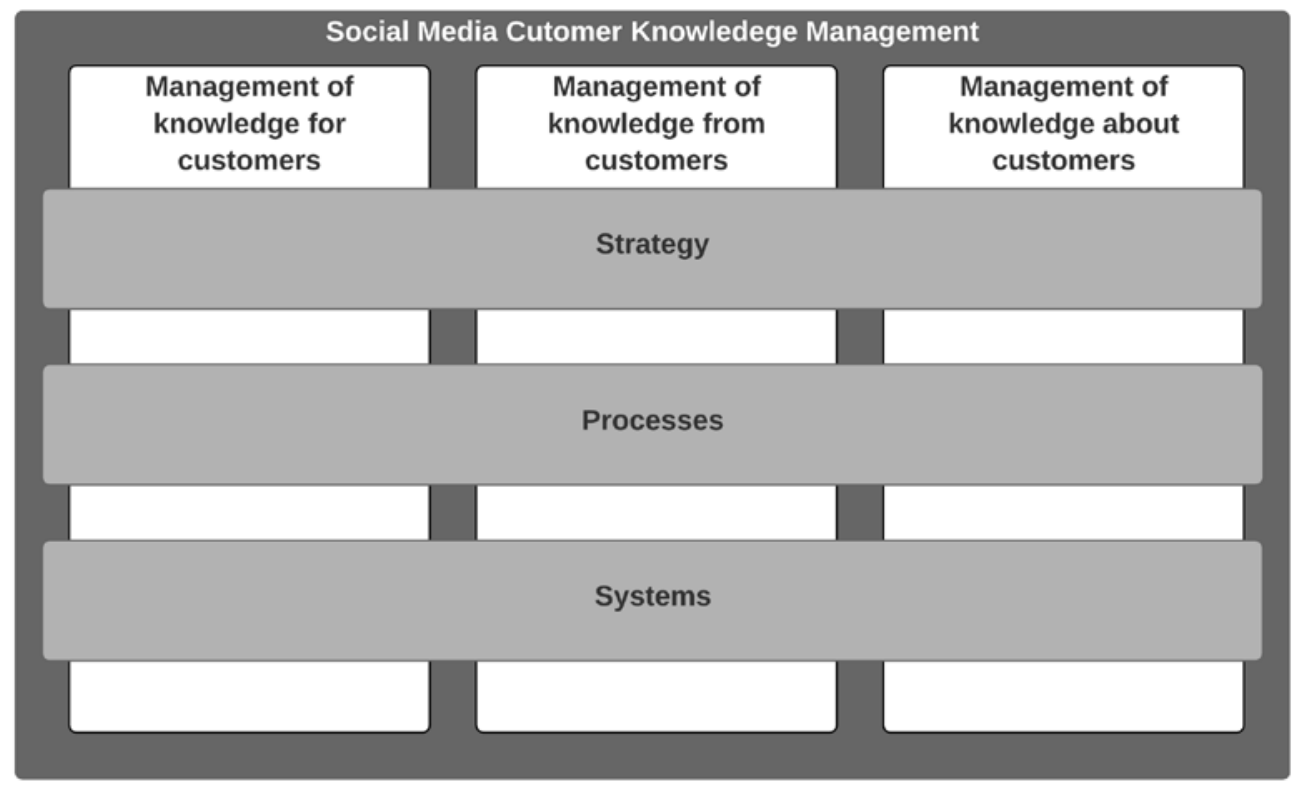

Figure 1. Social Media for Customer Knowledge Management in Practice

\section{RESEARCH METHODOLOGY}

The Preferred Reporting Items for Systematic Reviews and Meta-Analyses (PRISMA) guidelines for conducting systematic reviews proposed by Liberati et al. (2009) was used to streamline the process for conducting this systematic review. The PRISMA guidelines consist of a 27-item checklist and a four-phase flow diagram that allows for transparent reporting of systematic reviews. By following this checklist, we ensured that other researchers could replicate the study.

\section{Data Sources and Search Strategy}

Three databases - ABI/Inform, ACM Digital Library, and EBSCO - was searched for relevant literature in the current study. Our search strategy targeted studies published in English between January 2010 and January 2020. The study period was appropriate to capture the relevant literature given that while internet use in low-income countries hovered around $42 \%$ as at 2013 , only $24 \%$ of adults owned a smartphone while $34 \%$ reported using social media (Pew Research Center, 2018). An independent search was also carried out on Google Scholar for grey literature that met the search criteria. The search query, in effect, captured studies on "social media" and "knowledge management" in relation to "customers".

\section{Eligibility Criteria}

Studies were considered eligible if they met the following criteria: a) clear and understandable research objective b) research objective discusses CKM in the context of social media, c) primary data from the study is collected from one of the IMF emerging and developing economies (IMF, 2020), and d) at least one of the four elements of CKM implementation is discussed. Studies that discussed exclusively CKM without the social media component were excluded. Similarly, studies that discussed KM but not in the context of customer knowledge were also excluded. 


\section{Evaluation Criteria}

As mentioned earlier, study evaluation of the selected studies were organized using the PRISMA methodology and the theoretical framework discussed in the previous section. An initial title and keyword review were conducted as a preliminary filtering mechanism, followed by an abstract review of the remaining papers. A final step studied the full text papers to answer our research questions on social media and CKM.

\section{RESULTS}

\section{Study Selection}

Figure 2 below depicts the workflow diagram which follows the PRISMA guidelines for the study selection based on the phases of this systematic review. The review includes all four phases of the guideline: study identification, screening, eligibility assessment and included articles. As illustrated, the search yielded 276 results from the targeted databases and 5 more records were added from targeted search on Google. (grey literature search). After duplicates were excluded, 263 unique records were retained to undergo title and abstract review. A careful title and abstract assessment eliminated 214 articles from the final set based on being: KM literature reviews (37), studies from developed countries (123); or completely unrelated to either KM or CKM (54). The 49 remaining articles underwent full text review out of which 16 records that met at least one of the areas of the conceptual framework were retained.

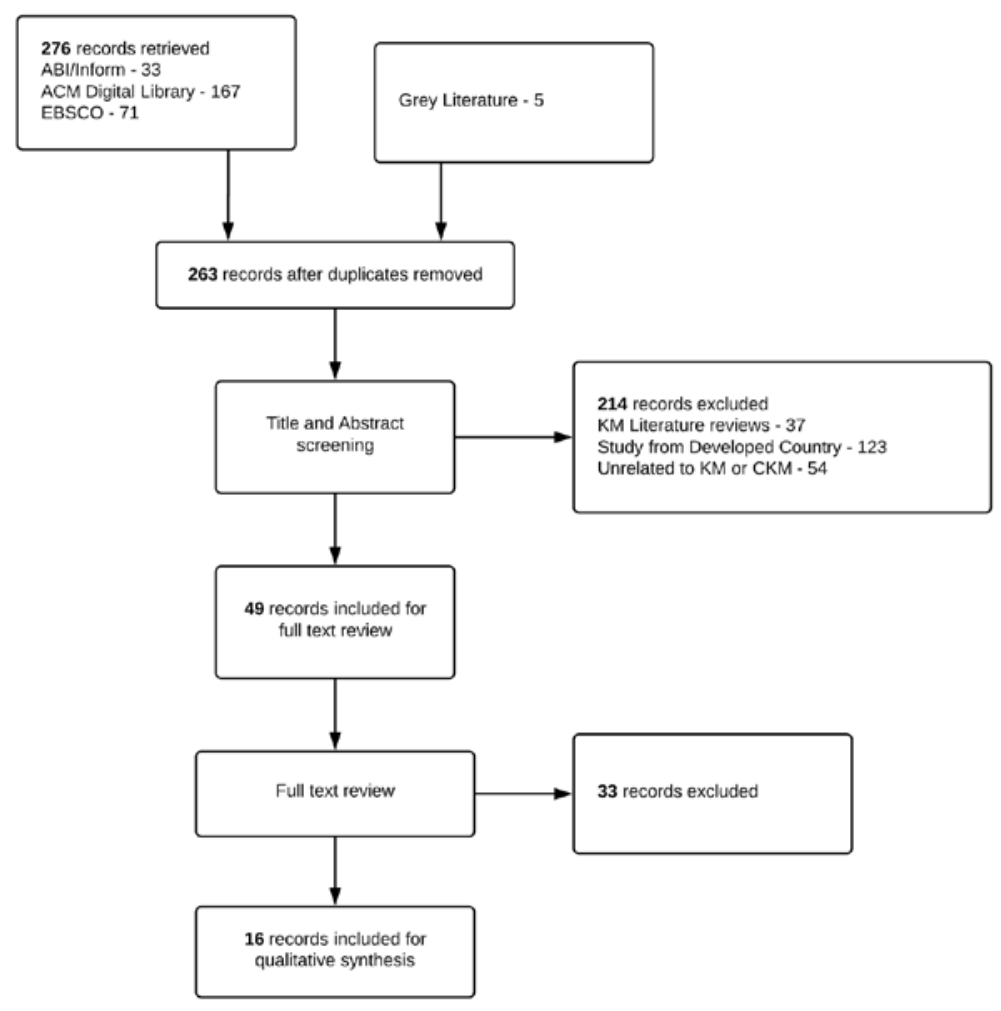

Figure 2. PRISMA flow chart for study selection

\section{Research Trends}

By examining the yearly distribution of studies on CKM (Figure 3), we identified that although several articles were published in 2017 than any other year, there was no clear publication trend by year as publications were randomly distributed. Table 1 also shows a similar distribution of publications by country and does not show a clear favorite in 
the distribution of publication countries. It must however be noted that India, Iran, and Nigeria had 3, 3, and 2 publications, respectively. All other countries (Colombia, Egypt, Ghana, Indonesia, Malaysia, Mexico, South Africa, and Thailand) included in this review had just 1 publication.

Of the studies included in this review 6 of them (Aghamirian et al., 2015; Kujur \& Singh, 2017; Kumar et al., 2017; Nwokah \& Irimagha, 2017; Ramachandran, 2013; Taherparvar et al., 2014) performed empirical research into CKM, a further 6 papers used a theoretical approach (Bello et al., 2017; Kaoud, 2017; Lak \& Rezaeenour, 2017; Picazo-Vela et al., 2011; Suzianti et al., 2019; Tabares et al., 2016). The remaining 4 papers (Boateng, 2016; Fashoro \& Barnard, 2017; Sołtysik-Piorunkiewicz, 2014; Valacherry \& Pakkeerappa, 2018) used a case study design.

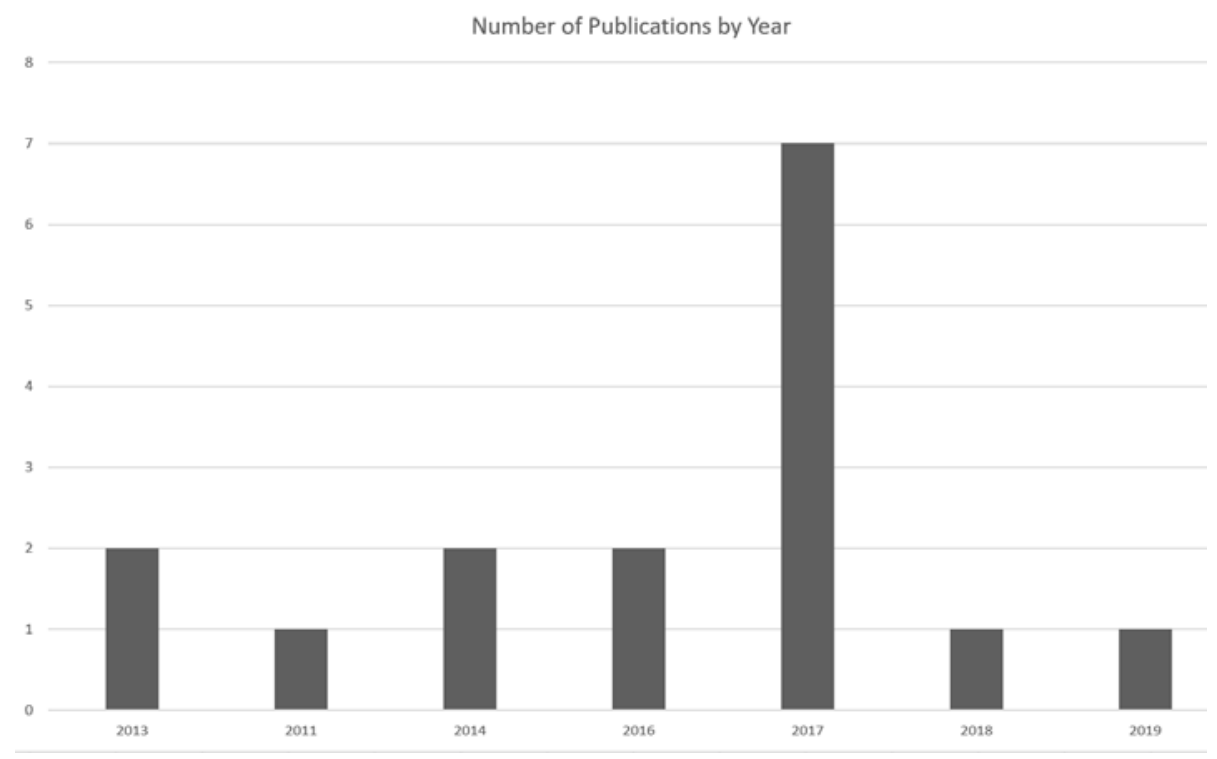

Figure 3. Publications by year

\section{Exploring the Research Questions}

To answer the research questions, the themes used in the studies were explored. It was discovered that 9 articles explored the strategies used by organizations to implement CKM in developing countries. Further, 7 papers discussed the CKM processes used to ensure customer success while 15 papers discussed various angles on how systems have been implemented. This is result is also summarized in Table 1.

\section{DISCUSSION}

\section{RQ1. Strategies used for CKM}

To ensure proper CKM in developing countries, the customer must be seen as a valuable resource whose knowledge leads to competitive advantage, that is, profitability in the short term and business sustainability in the long term (Aghamirian et al., 2015). The need for sound CKM strategies have been reiterated in the literature and transcends industries such as banking and insurance (Aghamirian et al., 2015; Kaoud, 2017), telecommunication (Boateng, 2016), and even governments (Fashoro \& Barnard, 2017; Picazo-Vela et al., 2011). Strategy management is important to give direction to the company by defining the scope and goals of each platform.

The result here was in line with a case study by Chua \& Banerjee (2013) on Starbucks where certain types of social media services were found to facilitate different strategies. Similarly, case studies of social media strategy in developing economies (Boateng, 2016; Valacherry \& Pakkeerappa, 2018), found that certain types social media services were used strategically for different types of CKM. Table 2 is a summary of their findings based on case studies in different countries (Ghana and India). 


\section{Issues in Information Systems \\ Volume 21, Issue 4, pp. 42-52, 2020}

Table 1. Summary of results

\begin{tabular}{|c|c|c|c|c|c|c|c|}
\hline Author & $\begin{array}{l}\text { Countr } \\
\text { y }\end{array}$ & Study Objective & $\begin{array}{l}\text { Study } \\
\text { Type }\end{array}$ & $\begin{array}{l}\text { Participants/Metho } \\
\text { ds }\end{array}$ & $\begin{array}{l}\text { RQ } \\
1\end{array}$ & $\begin{array}{l}\text { RQ } \\
2\end{array}$ & $\begin{array}{l}\text { RQ } \\
3\end{array}$ \\
\hline $\begin{array}{l}\text { (Aghamirian et al., } \\
\text { 2013) }\end{array}$ & Iran & $\begin{array}{l}\text { Investigating the relationship and application of } \\
\text { customer's knowledge management in gaining } \\
\text { competitive advantages of organizations in E- } \\
\text { commerce }\end{array}$ & Empirical & $\begin{array}{l}\text { Samples (394) from } \\
\text { banking and insurance } \\
\text { companies in Iran }\end{array}$ & $\mathrm{x}$ & $\mathrm{x}$ & $\mathrm{x}$ \\
\hline (Bello et al., 2017) & Nigeria & $\begin{array}{l}\text { Exploring the possibility of interdependency and } \\
\text { proposed a framework that integrates the } \\
\text { concepts of social media (SM), customer } \\
\text { relationship management (CRM) and knowledge } \\
\text { management (KM) to make a case for the } \\
\text { process framework for business organizations. }\end{array}$ & Theoretical & $\begin{array}{l}\text { Experts }(7) \text { in the } \\
\text { industry were identified } \\
\text { and consulted via email } \\
\text { and LinkedIn }\end{array}$ & $\mathrm{x}$ & $\mathrm{x}$ & $\mathrm{x}$ \\
\hline (Boateng, 2016) & Ghana & $\begin{array}{l}\text { Ascertaining the degree to which two } \\
\text { multinational telecom companies operating in } \\
\text { Ghana employ social media to assist in customer } \\
\text { knowledge management. }\end{array}$ & Case Study & $\begin{array}{l}\text { Netnography through } \\
\text { mining of Ghanaian } \\
\text { telecommunication } \\
\text { companies' social media } \\
\text { pages }\end{array}$ & $\mathrm{x}$ & $\mathrm{x}$ & $\mathrm{x}$ \\
\hline $\begin{array}{l}\text { (Fashoro \& Barnard, } \\
\text { 2017) }\end{array}$ & $\begin{array}{l}\text { South } \\
\text { Africa }\end{array}$ & $\begin{array}{l}\text { explores the challenges in Social Media } \\
\text { adoption in this municipality based on } \\
\text { interviews with the Communications department } \\
\text { who are responsible for both offline and online } \\
\text { communications }\end{array}$ & Case Study & $\begin{array}{l}\text { Five members of the } \\
\text { team who directly } \\
\text { interact with Social } \\
\text { Media were interviewed }\end{array}$ & $\mathrm{x}$ & & $\mathrm{x}$ \\
\hline (Kaoud, 2017) & Egypt & $\begin{array}{l}\text { Presenting an in-depth investigation of } \\
\text { Customer Knowledge Management through the } \\
\text { CRM business processes. }\end{array}$ & Theoretical & $\begin{array}{l}\text { Semi-structured } \\
\text { interviews and direct } \\
\text { observation of Deraya } \\
\text { Insurance Brokerage } \\
\text { Firm in Egypt }\end{array}$ & $\mathrm{x}$ & & $\mathrm{x}$ \\
\hline (Kujur \& Singh, 2017) & India & $\begin{array}{l}\text { explore factors influencing consumer's online } \\
\text { engagement in social networking sites (SNS) }\end{array}$ & Empirical & $\begin{array}{l}\text { Questionnaires } \\
\text { administered to } \\
\text { respondents of different } \\
\text { educational } \\
\text { levels and diverse } \\
\text { locations in India }\end{array}$ & $\mathrm{x}$ & & $\mathrm{x}$ \\
\hline (Kumar et al., 2017) & India & $\begin{array}{l}\text { Empirically study the customer perception of } \\
\text { 'customer knowledge management (CKM) } \\
\text { translation into customer communication value } \\
\text { and the impact on intention to purchase from } \\
\text { Ecommerce firms in Indian context'. }\end{array}$ & Empirical & $\begin{array}{l}\text { Structured survey } \\
\text { questionnaire from } 76 \\
\text { respondents from social } \\
\text { media, colleagues, and } \\
\text { undergraduate students }\end{array}$ & & & $\mathrm{x}$ \\
\hline $\begin{array}{l}\text { (Lak \& Rezaeenour, } \\
\text { 2017) }\end{array}$ & Iran & $\begin{array}{l}\text { explores and discusses, through qualitative } \\
\text { research, the risks that companies would face by } \\
\text { using Facebook's engagement platform and } \\
\text { related implications }\end{array}$ & $\begin{array}{l}\text { Theoretical } \\
\text { and } \\
\text { Empirical }\end{array}$ & $\begin{array}{l}\text { Managers and } \\
\text { professionals and } \\
\text { organizations providing } \\
\text { electronic services in } \\
\text { Iran }\end{array}$ & & & $\mathrm{x}$ \\
\hline $\begin{array}{l}\text { (Picazo-Vela et al., } \\
\text { 2011) }\end{array}$ & Mexico & $\begin{array}{l}\text { introduce some perceived risks and benefits } \\
\text { from public managers from Mexico, but mainly, } \\
\text { important strategic elements to include social } \\
\text { media in e-government strategies }\end{array}$ & Theoretical & $\begin{array}{l}\text { Five focus groups as part } \\
\text { of symposium in Mexico } \\
\text { City }\end{array}$ & $\mathrm{x}$ & $\mathrm{x}$ & $\mathrm{x}$ \\
\hline $\begin{array}{l}\text { (Nwokah \& Irimagha, } \\
\text { 2017) }\end{array}$ & Nigeria & $\begin{array}{l}\text { empirically investigate how E-Marketing } \\
\text { Orientation relates with Social Media } \\
\text { Implementation in the Banking Industry in } \\
\text { Nigeria }\end{array}$ & Empirical & $\begin{array}{l}\text { Cross-sectional survey } \\
\text { of } 3121 \text { staff listed in the } \\
\text { Bankers Association of } \\
\text { Nigeria }\end{array}$ & & & $\mathrm{x}$ \\
\hline (Ramachandran, 2013) & Malaysia & $\begin{array}{l}\text { aimed at gauging sector level capability, which } \\
\text { is a culmination of organizational or firm level } \\
\text { capability }\end{array}$ & Empirical & $\begin{array}{l}\text { survey of } 271 \text { ICTS } \\
\text { companies in Malaysia }\end{array}$ & & & $\mathrm{x}$ \\
\hline $\begin{array}{l}\text { (Soltysik-Piorunkiewicz, } \\
\text { 2014) }\end{array}$ & Thailand & $\begin{array}{l}\text { compare selected blogs from telecommunication } \\
\text { sector company operating in Poland and to } \\
\text { evaluate them from user-centered perspective }\end{array}$ & $\begin{array}{l}\text { Comparativ } \\
\text { e }\end{array}$ & $\begin{array}{l}\text { Observation of three } \\
\text { companies from } \\
\text { telecommunications } \\
\text { industry in Poland }\end{array}$ & $\mathrm{x}$ & $\mathrm{x}$ & $\mathrm{x}$ \\
\hline (Suzianti et al., 2019) & Indonesia & $\begin{array}{l}\text { implementation of integrated knowledge } \\
\text { management across sectors that will be involved } \\
\text { in this concept of social innovation }\end{array}$ & $\begin{array}{l}\text { Theoretical } \\
\text { and Design } \\
\text { Science }\end{array}$ & $\begin{array}{l}\text { Secondary data, } \\
\text { questionnaire research to } \\
\text { target the civilian sector } \\
\text { and in-depth interviews } \\
\text { for the government and } \\
\text { corporation sector and } \\
\text { focus group discussions. }\end{array}$ & & $\mathrm{x}$ & \\
\hline
\end{tabular}


Table 1. Summary of results

\begin{tabular}{|c|c|c|c|c|c|c|c|}
\hline Author & $\begin{array}{l}\text { Countr } \\
\mathbf{y}\end{array}$ & Study Objective & $\begin{array}{l}\text { Study } \\
\text { Type }\end{array}$ & $\begin{array}{l}\text { Participants/Method } \\
\text { s }\end{array}$ & $\begin{array}{c}\text { RQ } \\
1\end{array}$ & $\begin{array}{c}\text { RQ } \\
2\end{array}$ & $\begin{array}{c}\text { RQ } \\
3\end{array}$ \\
\hline (Tabares et al., 2016) & Colombia & $\begin{array}{l}\text { proposes a way to integrate the knowledge } \\
\text { management to the organizational strategy } \\
\text { through the business processes management }\end{array}$ & $\begin{array}{l}\text { Theoretica } \\
\text { l and } \\
\text { Design } \\
\text { Science }\end{array}$ & $\begin{array}{l}\text { A survey in } 40 \\
\text { Colombians' companies } \\
\text { about the state of the } \\
\text { practice in BPM, } \\
\text { information } \\
\text { management, and } \\
\text { knowledge management }\end{array}$ & & & $\mathrm{x}$ \\
\hline $\begin{array}{l}\text { (Taherparvar et al., } \\
\text { 2014) }\end{array}$ & Iran & $\begin{array}{l}\text { examine the effect of customer knowledge } \\
\text { management (CKM) on continuous innovation } \\
\text { and firm performance in } 35 \text { private banks in } \\
\text { Guilan (Iran). }\end{array}$ & Empirical & $\begin{array}{l}\text { Data collected from } 350 \\
\text { bank managers }\end{array}$ & & & $\mathrm{x}$ \\
\hline $\begin{array}{l}\text { (Valacherry \& } \\
\text { Pakkeerappa, 2018) }\end{array}$ & India & $\begin{array}{l}\text { proposes and validates a conceptual model that } \\
\text { explicates customers' adoption intention toward } \\
\text { co-creativity to develop new services in hotels }\end{array}$ & $\begin{array}{l}\text { Case } \\
\text { Study }\end{array}$ & $\begin{array}{l}\text { Netnography through } \\
\text { mining of Indian } \\
\text { retailing company's } \\
\text { social media pages }\end{array}$ & $\mathrm{x}$ & $\mathrm{x}$ & $\mathrm{x}$ \\
\hline
\end{tabular}

Additionally, regardless of strategy, Bello et al. (2017) posited that three CKM activities that have been greatly impacted by social media and could be effective for aligning strategy include: channel, engagement and intelligence interaction management.

- Channel Management. These refer to the activities done to ensure all the companies' channels are in sync with each other. Due to unpredictable nature of customers in developing economies as compared to those in developed countries, organizations will have to ensure that all other channels (radio, television, face-to-face etc.) are reiterating the same message being broadcast on social media. To instill confidence in information and to avoid conflict there should be information synchronization that is ideally authorized by a senior team member (Fashoro \& Barnard, 2017).

- Engagement Management. This strategy requires that the organization perform a bidirectional rather than a unidirectional approach in any of its social media channels. To encourage participation culture and ensure improved decision making for sustainability and profitability, all channels should act as a platform to both disseminate and receive information (Aghamirian et al., 2015; Bello et al., 2017; Kujur \& Singh, 2017; Picazo-Vela et al., 2011).

- Intelligence Interaction Management. The resurgence of artificial intelligence and natural language processing means now business can automate knowledge from customers by using business intelligence systems that measure key performance indicators of the company using social media posts. Just as researchers (Boateng, 2016; Valacherry \& Pakkeerappa, 2018) were able to gather valuable information on how CKM is handled by organization, it would be relevant for the organization to also analyze the streams of data using automated tools that such as those inbuilt to the social media platforms (examples include Facebook Insights and Twitter Analytics) or external ones (such as Brandwatch Consumer Research and BuzzSumo) which specialize in this area by allowing organizations to monitor their social media platform in real-time and supplying different types of engagement metrics.

Table 2. Social media strategies

\begin{tabular}{|c|c|c|c|}
\hline Social Media Network & Knowledge for Customers & Knowledge from Customer & Knowledge about Customer \\
\hline $\begin{array}{l}\text { Social networking } \\
\text { Facebook }\end{array}$ & $\begin{array}{l}\text { Information on current products, } \\
\text { services, and service challenges }\end{array}$ & $\begin{array}{l}\text { Solicit information on brand, product, } \\
\text { and service quality such as location- } \\
\text { based issues }\end{array}$ & $\begin{array}{l}\text { Identify demographics, customer } \\
\text { needs, and changing preferences }\end{array}$ \\
\hline $\begin{array}{l}\text { Microblogging } \\
\text { Twitter }\end{array}$ & $\begin{array}{l}\text { Detailed changes such as pricing } \\
\text { information and product promotion }\end{array}$ & $\begin{array}{l}\text { Insights on customer needs and } \\
\text { preference, as well as competitor } \\
\text { information }\end{array}$ & $\begin{array}{l}\text { Identify demographics, customer } \\
\text { needs, and changing preferences; }\end{array}$ \\
\hline $\begin{array}{l}\text { Location aware } \\
\text { Foursquare }\end{array}$ & $\begin{array}{l}\text { Location of stores, offers and other } \\
\text { location-based services }\end{array}$ & $\begin{array}{l}\text { Information on quality of products } \\
\text { and services based on location }\end{array}$ & $\begin{array}{l}\text { Location and ratings of stores most } \\
\text { frequented by customers }\end{array}$ \\
\hline
\end{tabular}

Adapted from case studies by (Boateng, 2016; Valacherry \& Pakkeerappa, 2018) 


\section{RQ2. CKM Processes for Ensuring and Promoting Customer Success}

Since the focus is on organizational knowledge, the current study employs the Socialization, Externalization, Combination, and Internalization (SECI) model of KM proposed by Nonaka \& Takeuchi (1995) to explain the activities and processes for engaging customers. The importance of knowledge discovery is highlighted by the literature. The studies reviewed captured the following:

- Socialization (Tacit to Tacit). CKM originates from the socialization aspect of KM (Valacherry \& Pakkeerappa, 2018). Through social media channels, there is a bidirectional engagement that ensure that organizations share - or customers request for - information about products and services (Aghamirian et al., 2015; Boateng, 2016; Suzianti et al., 2019; Valacherry \& Pakkeerappa, 2018). In other instances, request for get recommendations on products through their friends on platforms like Facebook and Twitter. The knowledge type created here includes all three: for, from, and about customers (Boateng, 2016; Valacherry \& Pakkeerappa, 2018).

- Externalization (Tacit to Explicit). Advertisements, events, manuals, tutorials and general product information are often made available as daily posts on social media, blogs, or even in the about section of the organization's website that are shared as knowledge for customers (Boateng, 2016; Soltysik-Piorunkiewicz, 2014; Valacherry \& Pakkeerappa, 2018).

- Combination (Explicit to Explicit). This is often in the form of tracking customer engagement, disseminating and collating surveys on customer experience etc. Often this is the best way to gather information from customers (Boateng, 2016; Valacherry \& Pakkeerappa, 2018).

- Internalization (Explicit to Tacit). A direct opposite to the externalization process, this is often where customers internalize (learn) about service and products information (Boateng, 2016; Valacherry \& Pakkeerappa, 2018)

\section{RQ3. Systems implementation to support Customer Relationship Management}

The prevalent systems for creating a knowledge repository across the organization and ensuring success can be discussed by adapting the core functions of customer relationship management Marketing, Sales, Customer Service (Kaoud, 2017), with a core distinction being Technology due to its importance to the whole idea of CKM (Aghamirian et al., 2015). In effect, on the marketing front, the teams ensure customers are kept engaged through virtual events on social media, creative hashtags, and even post messages regarding the company's internal culture. While knowledge from customers is often discussed in terms of customer complaints, these marketing campaigns allow the team to answer questions and queries on brand values and even the events themselves (knowledge for customers) while the feedback from engagement with these posts provide insight into how customers are reacting to their entire brand (knowledge from customers) (Boateng, 2016; Valacherry \& Pakkeerappa, 2018). On the other hand, the Sales teams perform similar tasks but geared towards the organizations product rather than the brand as seen with the marketing departments (Kaoud, 2017).

The customer service and technical back office teams perform two interrelated but different tasks. While customer service performs qualitative tasks based on service management, complaint and opportunity management by answering queries (knowledge from customers), exploring complain trends (knowledge about customers) and placing loyalty and renewal calls (knowledge for customers), the technical team does this through empirical and quantitative means (Kaoud, 2017). This is sometimes in the form of exploring which communities are experiencing difficulties and reaching out to customers identified on social media directly (Boateng, 2016; Valacherry \& Pakkeerappa, 2018).

\section{CONCLUSION}

Past research has posited that customers, through their use of a firm's products and services, gain knowledge and experience which can be viewed as an important resource for the firm. By collecting and analyzing information from 


\section{Issues in Information Systems}

Volume 21, Issue 4, pp. 42-52, 2020

customers and creating knowledge from them, businesses can obtain competitive advantage. The objective of this research was to analyze the extent to which social media supports customer knowledge management (CKM) in developing economies through the theoretical lens of social capital and resource exchange. The current study synthesized extant literature on social media and CKM. The findings in this study show that the strategies employed in developing economies were largely depends on the type of social media and strategies can be made effective through channel, engagement, and business intelligence. It was also discovered that knowledge creation was the most important KM process for ensuring success whiles the systems that support this were a combination of Marketing, Sales, Customer Service and Technology. The study found that there is a requirement for organizations, especially those in developing economies, to consider the importance of customer knowledge by creating repositories of customer knowledge to reduce uncertainty, align channels to communicate the same information across said channels. There is also an added requirement to pay attention to nascent technologies for monitoring customer trends in a bid to ensure innovation and creativeness.

This study is not without its limitations. The relevant literature was collected from only subscription databases with few more studies collected from Google Scholar. This may not be representative of the body of work in this field. given that authors in developing economies could publish in other lesser known or non-peer reviewed journals (Bentley, 2015). The authors recognize this limitation and recommend other studies of this nature to include non-peer reviewed sources.

While this study aimed to discuss $\mathrm{KM}$ on developing economies, further studies is required to compare and contrast the findings with developed economies in the context culture and engagement. Along the same line, a meta-analysis that uses quantitative techniques to determine which strategies work best based in previous studies may be considered. Further, future studies on the impact of customer knowledge on corporate product innovation and performance is also encouraged.

\section{REFERENCES}

Aghamirian, B., Dorri, B., \& Aghamirian, B. (2015). Customer Knowledge Management Application in Gaining Organization's Competitive Advantage in Electronic Commerce. Journal of Theoretical and Applied Electronic Commerce Research, 10(1), 63-78. https://doi.org/10.4067/S0718-18762015000100006

Applegate, L. M., Austin, R. D., \& Soule, D. L. (2009). Corporate information strategy and management: Text and cases (8th ed). Boston : McGraw-Hill Irwin. https://trove.nla.gov.au/work/14050843

Bello, O. W., Folarin, M., \& Faruk, N. (2017). Towards a Framework for Integrating Social Media, Customer Relationship, and Knowledge Management. In W. Al-Rabayah, R. Khasawneh, R. Abu-shamaa, \& I. Alsmadi (Eds.), Strategic Uses of Social Media for Improved Customer Retention: IGI Global. http://services.igiglobal.com/resolvedoi/resolve.aspx?doi=10.4018/978-1-5225-1686-6

Bentley, P. J. (2015). Cross-country differences in publishing productivity of academics in research universities. Scientometrics, 102(1), 865-883. https://doi.org/10.1007/s11192-014-1430-4

Boateng, H. (2016). Customer knowledge management practices on a social media platform: A case study of MTN Ghana and Vodafone Ghana. Information Development, 32(3), 440-451. https://doi.org/10.1177/0266666914554723

Chua, A. Y. K., \& Banerjee, S. (2013). Customer knowledge management via social media: The case of Starbucks. Journal of Knowledge Management, 17(2), 237-249. https://doi.org/10.1108/13673271311315196

Davenport, T. H., Harris, J. G., \& Kohli, A. K. (2001). How Do They Know Their Customers So Well. /paper/HowDo-They-Know-Their-Customers-So-Well-DavenportHarris/4dea5a8174336a6329e35ed4c672141b35a0a03f 
Desouza, K. C., \& Awazu, Y. (2005). What do they Know? Business Strategy Review, 16(1), 41-45. https://doi.org/10.1111/j.0955-6419.2005.00351.x

Dous, M., Kolbe, L., Salomann, H., \& Brenner, W. (2005). Knowledge Management Capabilities in CRM: Making Knowledge For, From and About Customers Work. 13.

Drucker, P. F. (1992, September 1). The New Society of Organizations. Harvard Business Review, SeptemberOctober 1992. https://hbr.org/1992/09/the-new-society-of-organizations

Fashoro, I., \& Barnard, L. (2017). Challenges to the Successful Implementation of Social Media in a South African Municipality. Proceedings of the South African Institute of Computer Scientists and Information Technologists. https://doi.org/10.1145/3129416.3129426

García-Murillo, M., \& Annabi, H. (2002). Customer knowledge management. Journal of the Operational Research Society, 53(8), 875-884. https://doi.org/10.1057/palgrave.jors.2601365

Gibbert, M., Leibold, M., \& Probst, G. (2002). Five Styles of Customer Knowledge Management, and How Smart Companies Use Them To Create Value. European Management Journal, 20(5), 459-469. https://doi.org/10.1016/S0263-2373(02)00101-9

IMF. (2020). World Economic Outlook Database, April 2020. International Monetary Fund. https://www.imf.org/external/pubs/ft/weo/2020/01/weodata/weoselagr.aspx

Kaoud, M. (2017). Investigation of Customer Knowledge Management: A Case Study Research. International Journal of Service Science, Management, Engineering, and Technology, 8(2), 12-22. https://doi.org/10.4018/IJSSMET.2017040102

Kaplan, A. M., \& Haenlein, M. (2010). Users of the world, unite! The challenges and opportunities of Social Media. Business Horizons, 53(1), 59-68. https://doi.org/10.1016/j.bushor.2009.09.003

Khodakarami, F., \& Chan, Y. E. (2014). Exploring the role of customer relationship management (CRM) systems in customer knowledge creation. Information \& Management, 51(1), $27-42$. https://doi.org/10.1016/j.im.2013.09.001

Kujur, F., \& Singh, S. (2017). Engaging customers through online participation in social networking sites. Asia Pacific Management Review, 22(1), 16-24. ABI/INFORM Collection. https://doi.org/10.1016/j.apmrv.2016.10.006

Kumar, A., M., M., \& Singh, Dr. S. (2017). Translating Customer Knowledge Management Into Perceived Customer Communication Value and Purchase Intention: A Study on Indian Ecommerce Firms. SSRN Electronic Journal. https://doi.org/10.2139/ssrn.3171945

Lak, B., \& Rezaeenour, J. (2017). Effective Factors of Social Customer Knowledge Management (SCKM) in Organisations: Study of Electronic Service Providers in Iran. Journal of Information \& Knowledge Management, 16(02), 1750014. https://doi.org/10.1142/S0219649217500149

Liberati, A., Altman, D. G., Tetzlaff, J., Mulrow, C., Gøtzsche, P. C., Ioannidis, J. P., Clarke, M., Devereaux, P. J., Kleijnen, J., \& Moher, D. (2009). The PRISMA statement for reporting systematic reviews and meta-analyses of studies that evaluate health care interventions: Explanation and elaboration. PLoS Medicine, 6(7), e1000100.

Nonaka, I., \& Takeuchi, H. (1995). The Knowledge-Creating Company: How Japanese Companies Create the Dynamics of Innovation. Oxford University Press.

Nwokah, N. G., \& Irimagha, B. B. (2017). E-Marketing Orientation and Social Media Implementation in the Banking Industry in Nigeria. IBusiness, 9(4), 111-133. https://doi.org/10.4236/ib.2017.94009 
Pew Research Center. (2018). Social Media Use Continues to Rise in Developing Countries but Plateaus Across Developed Ones. 46.

Picazo-Vela, S., Gutiérrez-Martinez, I., \& Luna-Reyes, L. F. (2011). Social Media in the Public Sector: Perceived Benefits, Costs and Strategic Alternatives. Proceedings of the 12th Annual International Digital Government Research Conference: Digital Government Innovation in Challenging Times, 198-203. https://doi.org/10.1145/2037556.2037587

Plessis, M. du, \& Boon, J. A. (2004). Knowledge management in eBusiness and customer relationship management: South African case study findings. International Journal of Information Management, 24(1), 73-86. https://doi.org/10.1016/j.ijinfomgt.2003.10.002

Ramachandran, R. (2013). Capability Determinants of Information \& Communications Technology Services (ICTS) Sector: A Malaysian Policy Perspective. Proceedings of the 7th International Conference on Theory and Practice of Electronic Governance, 116-119. https://doi.org/10.1145/2591888.2591907

Rowley, J. (2002). Eight questions for customer knowledge management ine-business. Journal of Knowledge Management, 6(5), 500-511. https://doi.org/10.1108/13673270210450441

Sołtysik-Piorunkiewicz, A. (2014). The Telecom Business Strategies: A Comparative Study of Corporate Blogs. Proceedings of the 2014 Mulitmedia, Interaction, Design and Innovation International Conference on Multimedia, Interaction, Design and Innovation, 1-11. https://doi.org/10.1145/2643572.2643592

Suzianti, A., Hafi, K. A., \& Shafira, N. D. (2019). Designing Indonesia Social Innovation Knowledge Management System: Case Study of Kreanovator Indonesia. Proceedings of the 5th International Conference on Communication and Information Processing, 184-190. https://doi.org/10.1145/3369985.3370005

Tabares, M. S., Giraldo, L., \& Joyanes, L. (2016). Improving the Business Processes Management from the Knowledge Management. Proceedings of the The 11th International Knowledge Management in Organizations Conference on The Changing Face of Knowledge Management Impacting Society. https://doi.org/10.1145/2925995.2925998

Taherparvar, N., Esmaeilpour, R., \& Dostar, M. (2014). Customer knowledge management, innovation capability and business performance: A case study of the banking industry. Journal of Knowledge Management, 18(3), 591610. https://doi.org/10.1108/JKM-11-2013-0446

Tseng, S.-M., \& Wu, P.-H. (2014). The impact of customer knowledge and customer relationship management on service quality. International Journal of Quality and Service Sciences, 6(1), 77-96. https://doi.org/10.1108/IJQSS-08-2012-0014

Valacherry, A. K., \& Pakkeerappa, P. (2018). Customer Knowledge Management via Social Media: A Case Study of an Indian Retailer. Journal of Human Values, 24(1), 39-55. https://doi.org/10.1177/0971685817733571

Vijay, A., \& Srivastava, A. (2019). Exploring the Dynamic Linkages between Social Media and Present Marketing Practices. International Journal on Customer Relations; New Delhi, 7(1), 26-35.

Winer, R. S. (2001). A Framework for Customer Relationship Management. California Management Review, 43(4), 89-105. https://doi.org/10.2307/41166102 